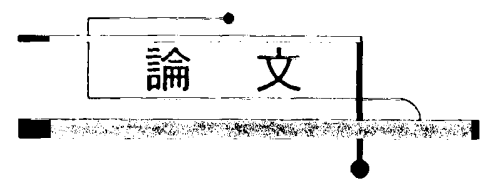

\title{
電磁誘導によるボイド率計測*
}

\section{Void Fraction Measurement by Using Electromagnetic Induction}

\author{
桑 原 拓 也** \\ 山口博 司 ${ }^{* * *}$ \\ KUWAHARA Takuya \\ YAMAGUCHI Hiroshi
}

\begin{abstract}
This paper describes a new measuring technique of void fraction using a magnetic fluid. The proposed measurement utilizes the electromagnetic induction so that the measurement can be realized with simple experimental devices. The present study consists of two kinds of experiments; one is "static experiment (calibration test)" and another is "flow experiment (actual flow test)". In the present study, the experiments have been performed with fully diluted magnetic fluid for the purpose of applying to the ordinary two-phase flows such as water-air two-phase flow. Results of the experiments have verified that the proposed measuring technique of void fraction is very effective to measure the void fraction in the two-phase flow by adding a small amount of the magnetic fluid to objective fluid.
\end{abstract}

Keywords: Void fraction, Magnetic fluid, Gas-liquid two-phase flow, Quick-closing valves

\section{1. 緒 言}

気液二:相流の基礎パラメータの計測は流動解 析やモデリング、実用において、非常に重要であ る。しかし、気液二相流の現象自身が複雑である ため、主要なパラメータの計測技術が不十分であ るのが現状である。中でも気相の体積割合を表す ボイド率は重要なパラメータである。これまでの ボイド率測定方法[1]としては差圧法、締切法、触 針法[2]、光ファイバープローブ法[3]、コンダク タンス法、X線を利用した方法などが挙げられる。 中でも、楴切法、触針法は比較的簡便に計測でき るため、広く用いられている。一方、これらの計 測方法にむいくつかの問題点が挙げられる[4]。例 えば、締切法に㧍いては計測時に流路を遮断する 必要があり連続的に計测できない。また、間欠性 のある流れや冎ボイド率領域では誤差が増大す るなどの問題がある。さらに、触針法においては、 気泡と接触させるセンサ一を非常に細くしなけ
ればならないなどの短所を有する。以上のことか ら、比較的低コストで容易な計测、また連続的に 計測が行なえ、且つ流路に特別な加工を施す必要 の無い計測力法が望まれる。

磁性流体滋場に感応する性質を持つ液体で 多くの忍用が提案され、研究が進められている[5]。 中でも、磁性流体の気液二相流を利用した灾用上 して、熱輸送装置やエネルギ変換装置が挙げられ [6-8]、これらの装置の中に存在するボイド率計測 についての研究が進められている。本研究では、 これらの磁性流体を用いた装置のみならず、徍気 一水のような通常の気液二相流にも心用できる新 しいボイド率測定方法として、微量の磁性流体を、 対象となる流体に添加し磁化を持たせ、電磁誘導 によりボイド率を計測する力法を提案する。本研 究では、実験により有用性および实用性を検訨す ることを目的とする。

*2005.11.12 受付

** 同志社大学大学院工学研究科博士課程後期課程 $\bar{T} 610-0321$ 京都府京田辺市多々羅都谷 1-3

TEL: (0774)65-7749 FAX: (0774)65-7749 E-mail: ete1301@mail4.doshisha.ac.jp

*** 同志社大学工学部機械システム工学科 


\section{2. 計測原理・理論}

一般に、磁束密度 $\boldsymbol{B}$ は以下のように表すことが できる。

$$
\mathbf{B}=\mu_{0}(\mathbf{H}+\mathbf{M})
$$

ここで、 $\mu_{0}$ は真空の透磁率、 $H$ は磁場の強さ、 $\boldsymbol{M}$ 滋場中に置かれた物質の磁化を表す。Fig.1 に本研究で提案したボイド率計測原理の模式図 を示す。

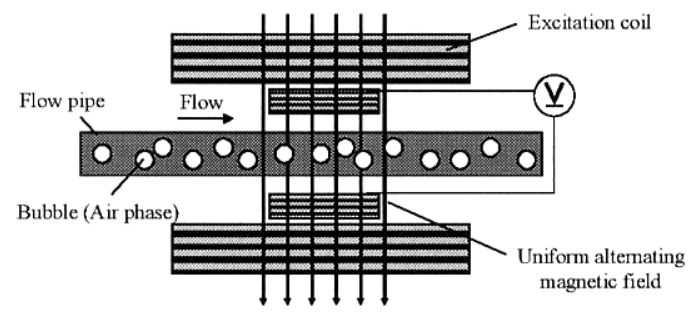

Fig.1 Principle of measurement

励磁コイルにより発生した一様な交番磁場中に 気液二相流が流れる流路が設置されている。気液 二相流の気相が空気 $\left(10^{-7}\right.$ オーダー) のように磁 化が無視できるほど小さい気体で、液相が気相と 比べて比較的大きな磁化を有する場合、気液二相 流を貫く磁束密度 $\boldsymbol{B}_{m f}$ は

$$
\mathbf{B}_{m f}=\mu_{0}\left\{\mathbf{H}+\mathbf{M}_{m i x}(\alpha)\right\}
$$

と表される。ここで、 $\boldsymbol{M}_{m i x}$ は気液二相状態での 見かけの磁化を表し、気相の体積割合であるボイ ド率 $\alpha$ の関数となる。水など多くの液体は磁化が 小さいものの、本研究では、液相が持っている流 体力学特性に影響を与えない微量の磁性流体を 液相に添加して液相に磁化を持たせる方法を提 案する。この方法では比較的弱い磁場を用いて計 測が行なえるため、コイル泠却も不要で装置が複 雑にならない。Fig.1 のように、二次コイルを交 番一様磁場中の流路上部および下部に設置した 場合、二次コイルに発生寸る誘導起電力 $\boldsymbol{V}$ は Faraday の電磁誘導の法則より、

$$
V=-n \frac{\partial}{\partial t} \iint_{S}\left[\mu_{0}\left\{\boldsymbol{H}+\boldsymbol{M}_{\text {mix }}(\alpha)\right\} \cdot \hat{\boldsymbol{n}}\right] \cdot d S
$$

となる。ここで、 $n$ は二次コイルの巻き数で、 $S$ は二次コイルの内面積である。本計測では磁場 $\boldsymbol{H}$ は一定で、液相の磁化も一定であるので、二次 コイルで発生する誘導起電力はボイド率 $\alpha$ の
の関数となる。言い換えれば、誘導起電力の值か らボイド率を計測することができる。ここで、気 液二相状態での見かけの磁化は、理論上、気液界 面で発生する磁気分極が小さいため、次のように 近似でき、誘導起電力とボイド率には線形関倸が 成り立つ。

$$
\begin{aligned}
\mathbf{M}_{m i x} & =\left(1-\alpha \frac{1+(1-\alpha) \chi_{m}}{(1-N)\left\{1+(1-\alpha) \chi_{m}\right\}+N}\right) \mathbf{M}_{m f} \\
& \cong(1-\alpha) \mathbf{M}_{m f}
\end{aligned}
$$

\section{3. 実験および方法}

\section{1 添加磁性流体濃度の選定}

本研究では、タイホー工業製水ベース磁性流体 W-40 液相に磁化を持たせるための磁性流体と して用いた。Dunouy 式表面張力測定器を用いて 表面張力を計測し、磁性流体の体積濃度と表面張 力の関係を調べた。その結果を Fig.2 に示す。結 果より濃度 10 [ $\mathrm{vol} \%]$ 以下になると表面張力が増 加し、さらに濃度 1 [ $\mathrm{vol} \%]$ 以下になると急激に増

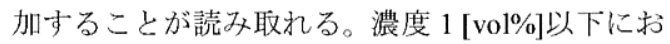
いては線形近似をすることができ、濃度が 0.1 vol\%減少することにより表面張力が 1.7 [ $\mathrm{mN} / \mathrm{m}]$ 増加する。本研究では、濃度 0.1 [ $[\mathrm{vol} \%$ ] 水により希釈した希釈磁性流体を供試流体とし て用いた。

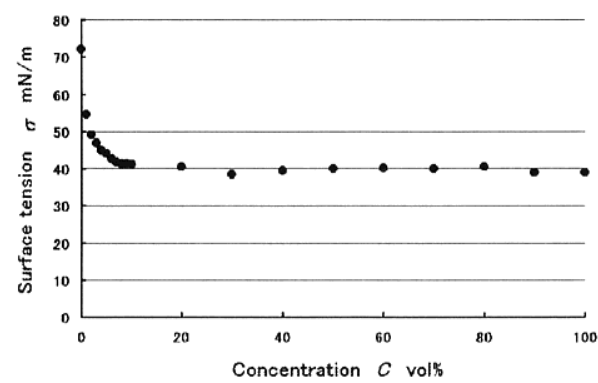

Fig.2 Concentration and surface tension

磁性流体 W-40 および本研究で用いた濃度が $0.1[\mathrm{vol} \%]$ の希釈磁性流体、蒸留水の物性を Table 1 に示寸。なお、濃度が 0.1 [ $\mathrm{vol} \%$ ] の希釈磁性流体 の表面張力に関しては上述のように表面張力計 測結果をもとに旅度 $1[\mathrm{vol} \%]$ 以下での線形近似に より求めた。 
Table 1 Properties of magnetic fluid, distilled water and diluted magnetic fluid of 0.1 [vol\%] (at 296K)

\begin{tabular}{|l|c|c|c|}
\hline & $\begin{array}{c}\text { Magnetic } \\
\text { Fluid (W-40) }\end{array}$ & $\begin{array}{c}\text { Diluted } \\
\text { Magnetic Fluid }\end{array}$ & $\begin{array}{c}\text { Distilled } \\
\text { Water }\end{array}$ \\
\hline Density $\left[10^{3} \mathrm{~kg} / \mathrm{m}^{3}\right]$ & 1.41 & 1.00 & 1.00 \\
\hline $\begin{array}{l}\text { Viscosity } \\
{[\mathrm{mPa} \cdot \mathrm{s}]}\end{array}$ & 18.85 & 1.011 & 1.008 \\
\hline $\begin{array}{l}\text { Surface tension } \\
{[\mathrm{mN} / \mathrm{m}]}\end{array}$ & 38.9 & 70.4 & 72.1 \\
\hline
\end{tabular}

希釈磁性流体と蒸留水を比較した場合、計測によ り、気液二相流の流動特性に影響を及ぼす密度、 粘度、表面張力において、值がほぼ等しいことが 確認された。計測は実験時と同じ室温 $23^{\circ} \mathrm{C}$ (296[K])で行なわれた。希釈磁性流体と蒸留水に おける表面張力の差が気泡体積に及ぼす影響を Laplace の式に基づいて計算した結果、 $1.2 \times 10^{-3}$ [\%]と非常に小さく、ボイド率計測に与える影響 を無視することができる。すなわち、ボイド率測 定の対象となる母液に濃度が $0.1[\mathrm{vol} \%$ ] うに磁性流体を添加することによりボイド率測 定が可能となる。

\section{2 実験装置}

本研究は誘導起電力とボイド率の関係を調べ る検定実験と実際の気液二相流において計測方 法の妥当性を検証寸る流動実験から成り立つ。

Fig.3 に検定実験で用いられた実験装置を示し、 Fig.4 に流動実験で用いられた実験装置を示す。 以下に実験装置を構成する主要な部分の詳細を 述べる。

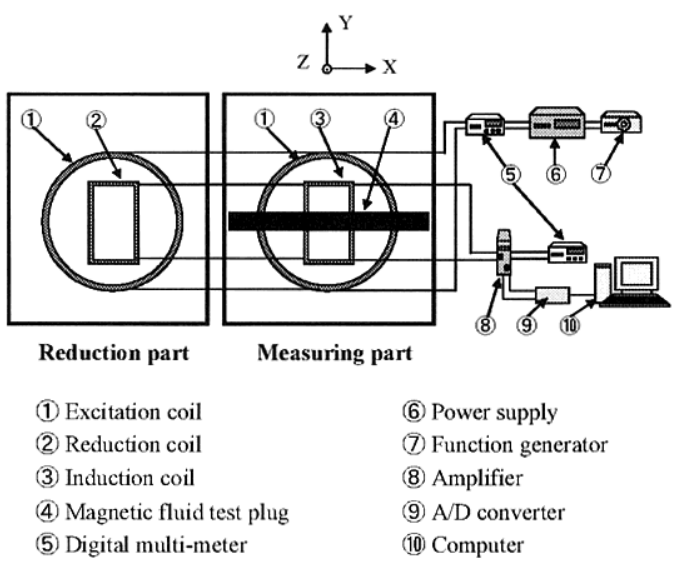

Fig.3 Experimental setup of calibration experiment

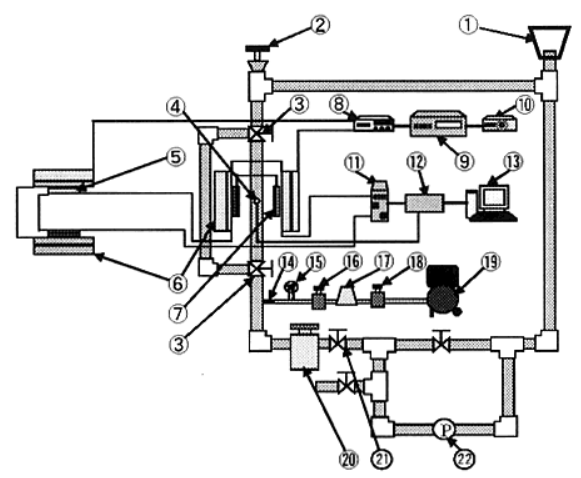

(1) Separator tank
(12) A/D converter
$\begin{array}{ll}\text { (2) Thermometer } & \text { (13) Computer } \\ \text { (3) Ball valve } & \text { (14) Air nozzle } \\ \text { (4) Pressure transducer } & \text { (15) Pressure gauge } \\ \text { (5) Reduction coil } & \text { (16) Mass flow rate controller } \\ \text { (6) Excitation coil } & \text { (11) Digital flow meter } \\ \text { (7) Induction coil } & \text { (18) Pressure regulating valve } \\ \text { (8) Digital multi-meter } & \text { (19) Air compressor } \\ \text { (9) Power supply } & \text { (20) Mass flow meter } \\ \text { (10) Function generator } & \text { (21) Needle valve } \\ \text { (11) Amplifier } & \text { (22) Pump }\end{array}$

Fig.4 Experimental setup of flow experiment

(1) 励磁コイル（Helmholtz コイル）

比較的広範囲な一様磁場を発生することので きる Helmholtz コイルを励磁コイルとして用いた。 Fig.5 にコイルの配置方法を示す。Fig.3 と Fig.4 に示されるように、励磁コイルは同仕様のものが 計測部分と減電圧部分に用いた。Fig.6 に励磁曰 イルの仕様を示す。一様磁場領域における磁場の 強さは 0.33[mT]であり、この值は一般の磁石（約 100[mT]）に比べると非常に小さな值であり、さ らに磁場が一様であることから、磁場が流れに及 ぼす影響は無視できる。

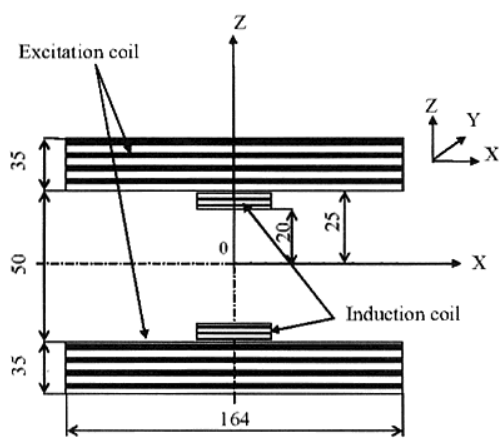

Fig.5 Arrangement of coils 


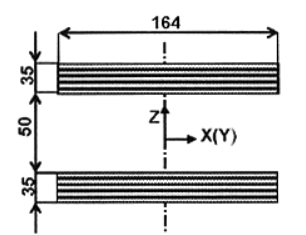

Diameter: $164 \mathrm{~mm}$

Thickness: $35 \mathrm{~mm}$

Winding turn: 107 turns

Diameter of copper wire: $0.5 \mathrm{~mm}$

Excitation coil (Helmholtz coil)

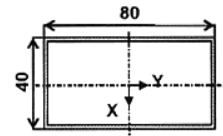

Thickness: $5 \mathrm{~mm}$

Winding turn: 150 turns

Diameter of copper wire: $0.1 \mathrm{~mm}$

Rectangle induction coil

Fig.6 Specifications of coils

(2) 二次コイル

二次コイルは一様磁場領域内に設置され、ボイ ド率の関数である誘導起電力を検出するために 用いられた。二次コイルは検定実験および流動実 験に㧍いて共通のコイルが用いられた。二次コイ ルの配置を Fig.5 に示し、二次コイルの仕様を

Fig.6 に示す。流路の上部および下部に設置され ている二次コイルは互いに同符号（同じ向き）の 起電力となるように直列に接続し、後述の減電圧 コイルとは逆起電力（逆符号、逆向き）になるよ うに直列に接続した。

(3) 減電圧コイル

減電圧コイルは、誘導起電力をコンピュータに 取り込むs A/D 変換器の最大入力が士10[V]である ことを考虑して、ボイド率計測に影響しない外部 磁場により発生する誘導起電力を差し消すため に用いられ、計測部の二次コイルと逆起電力にな るように接続し、減電圧部に設置する。すなわち、 減電压コイルにより、磁性流体による誘導起電力 のみをデータとしてコンピュータに取得できる。

(4) 希釈磁性流体テストプラグ

検定実験に用いた希釈磁性流体テストプラグ をFig.7 に示す。パイプ内の断面ボイド率が 0〜 0.10 まで 0.10 刻みになるようにあらかじめ計量 した希釈磁性流体が封入されている。Fig.3 に示 すように、検定実験において磁性流体テストプラ グは水平状態に設置し、ボイド率と誘導起電力の 関係を求めた。なお、磁性流体テストプラグは内 径 12 [mm]、長さ $300[\mathrm{~mm}]$ のアクリルパイプであ る。

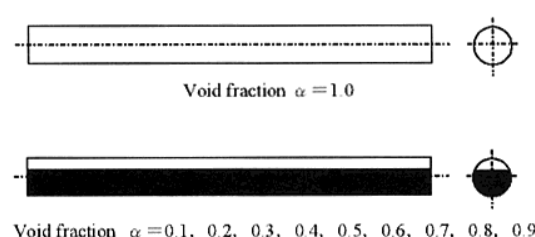

Void fraction $\alpha=01,02,0.3,04,0.5,0.6,0.7,0.8,0.9$

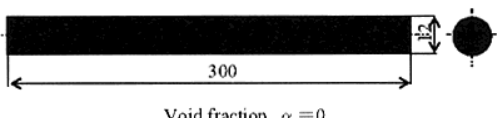

Fig.7 Magnetic fluid test plugs

(5) データ処理システム

二次コイルにより得たれた誘導起電力は瞬時 に A/D 変換器を通して、ディジタルデータとし てコンピュータに送られ、コンピュータに保存さ れる。サンプリング周波数は $10000[\mathrm{~Hz}]$ でサンプ リング件数は 30000 である。すなわち、ボイド率 計測は 3 秒間行なわれた。また、圧力や各相の流 量も同様にディジタルデータとしてコンピュー 夕に送られ保存される。A/D 変換器の仕様は最大 入力が士 $10[\mathrm{~V}]$ で分解能が 16[bits]である。データ 処理システムの時間応答性は $10^{-5}[\mathrm{~s}]$ である。なお、 磁性流体そのものによる時間応答性は $10^{-6}[\mathrm{~s}]$ で あり、これは Brown 緩和時間の值である。

(6) 空気注入システム

Fig.4 に示すように、磁性流体中に気泡を混入 し、気液二相流を実現するための気泡混入部は、 エアーコンプレッサー、オイルフィルター、定圧 力調整弁、電子式ガス流量計、流量制御バルブに より構成されている。エアーコンプレッサーで発 生した空気は定圧力調整弁によって制御され、圧 力変動が無い空気が流路に供給される。本実験で 使用した流量制御バルブには、出口側の圧力変動 に対して、一定流量を安定に制御可能なバルブを 使用した。また、流路に空気を注入するインジェ クタには径が $0.1[\mathrm{~mm}]$ の 2 つの銅パイプが用いら れた。2つの銅パイプは、空気注入時にインジェ クタ近傍での気泡の合体をできるだけ避けるた

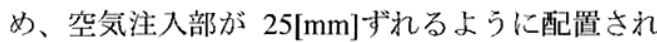
ている。

\section{3 実験手順}

本研究は、前述の通り、ボイド率と誘導起電力 の関係を直接求めるための水平・静止状態での実 験と実際の気液二相流におけるボイド率と誘導 
起電力の関傒を求める流動状態での実験とで構 成されている。前者は㭘定実験と呼称され、ボイ ド率と誘導起電力の関係を示寸検定線を作成す るため実験である。後者恃流動実験と呼称され、 ボイド率を締切法により求め、同時に誘導起電力 を測定することにより、流動状態におけるボイド 率と誘導起電力の関係を求めるための実験であ る。検定実験で得られた検定線と流動実験で得ら れた実験デー夕を比較検討することにより、本研 究で提案されたボイド率測定方法の実用性を検 証する。実験条件およびデー夕処理方法は対応す る両実験で同じである。各実験の詳細を以下に示 す。

\section{（1）検定実験}

検定実験はボイド率と誘導起電力の関係を調 心゙、流動実験に用いる検定線を作成するための実 験であり、Fig.3 に示すように誘導起電力は一様 磁場領域に磁性流体テストプラグを挿入するこ とにより求められる。得られた誘導起電力は $\mathrm{A} / \mathrm{D}$ 変換器によりディジタル化されコンピュータに 記録される。ディジタル化された誘導起電力デー 夕を用いて実効值を求めた。本研究で注、希䄷磁 性流体によって発生する誘導起電力、寸なわち、 得られた誘導起電力からボイド率 1.0 (空気のみ) の誘導起電力を差し引いた電圧を検出起電力 $\Delta V$ と呼称し、主要パラメータとして用いた。

$$
\Delta V=V_{R M S(\alpha=\alpha)}-V_{R M S(\alpha=1.0)}
$$

\section{（2）流動実験}

Fig.4 に示寸流動実験における実験装置におい て、希釈磁性流体はポンプにより流路を時計回り に循環する。流路内径は磁性流体テストプラグと 同じ 12[mm] である。空気インジェクタにより誘 導起電力計測部において気液二相流を実現する ことができる。注入された気泡はセパレータタン クにより大気中に放出され、液相のみが再循環す る。誘導起電力計測部の上部および下部には空気 圧作動アクチュエータを装備したボール弁が設 置されている。流動実験においてボイド率は、誘 導起電力計測部の上部および下部に設置された 2 つのボール弁を同時に瞬間的に閉弁し、閉弁後に 気相と液相が分離させ、液相の高さよりボイド率 を算出する、いわゆる締切法により計測した。な お、ボール弁を締め切る際に管内の圧力変動を圧 力変換器により観測した。圧力変動が比較的小さ
い場合に計測されたボイド率をデータとして採 用したものの、さらに圧力変動によるボイド率の 修正をBoyleの法則に基づいて算出された以下の 式を用いて行なった。

$$
\alpha_{1}=\frac{P_{2}}{P_{1}} \alpha_{2}
$$

ここで、 $\alpha$ はボイド率、P は圧力を表し、添え 字の 1 は締切前、2 2 締切後を意味する。

\section{4. 結果および考察}

\section{1 流動可視化実験}

希釈磁性流体および蒸留水の物性計測により、 両物性はほぼ同じ值であることを確認したもの の、微量でも不純物を含む場合は流動に影響党及 ぼす可能性が指摘されている。そこで、検定実験 および流動実験に先立ち、特に希釈磁性流体と蒸 留水における表面張力の差が流動様式に及ぼす 影響を確認するために、同流動条件下で流動可視 化実験を行った。Fig.8 に代表的な可視化実験結 果（気泡流、スラグ流、チャーン一與状流）を示 す。左側に蒸留水、右側に希釈磁性流体の可視化 写真を示す。

流動可視化実験では、希釈磁性流体および蒸留 水において流動および流動様式の異差は確認さ れなかった。そのため、0.1[ $\mathrm{vol} \%]$ の希釈磁性流体 でのボイド率計測実験は妥当なものと判断した。

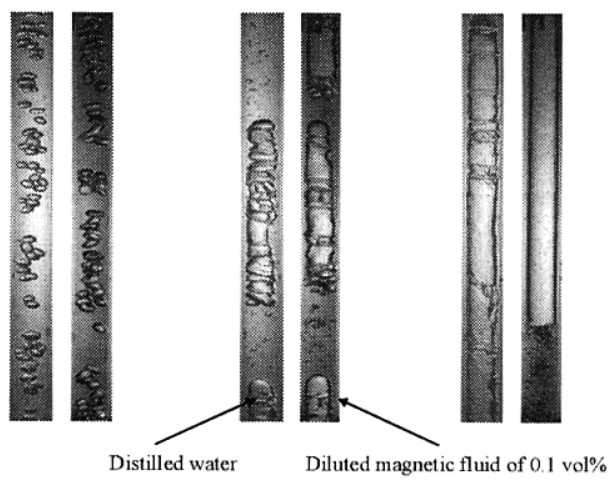

Fig.8 Results of visualization experiment

\section{2 検定実験}

検定実験で得られた結果を Fig.9に示す。なお、 励磁ヨイルの印加電流 $0.25[\mathrm{~A}]$ 、周波数 $1000[\mathrm{~Hz}]$ 、 増幅器のゲイン 500 で実験を行った。Fig.9 の結 
果から検出起電力とボイド率との間には良好な 線形関係が成り立つことが分かる。すわなち、検 定実験の結果からも気泡の気液界面における磁 気分極の影響は非常に小さいことが確認された。 なお、本研究では、得られた実験デー夕を線形近 似した直線を検定線と呼称し、流動実験で得られ た結果との比較に用いられた。

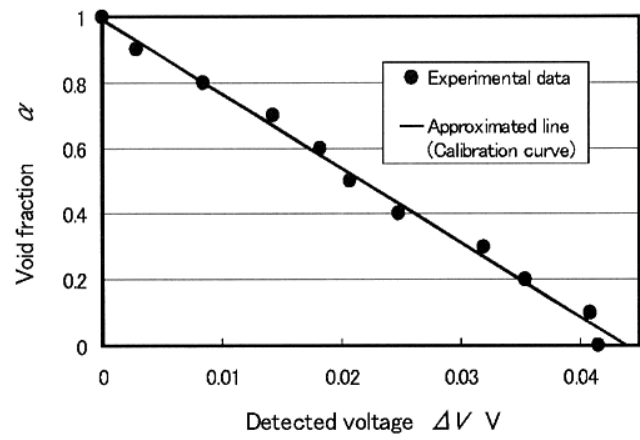

Fig.9 Results of calibration experiment

\section{3 流動実験（締切法による検証）}

流動実験は、検定実験と同じ、励磁コイルの印 加電流 $0.25[\mathrm{~A}]$ 、周波数 $1000[\mathrm{~Hz}]$ 、増幅器のゲイ ン 500 で行われた。流動に関する実験条件を Table 2 に示す。 流動条件は、流動実験でボイド 率計測に用いられる締切法で迤間欠性のある流 れや高ボイド率領域では誤差が大きいこと、さら に流動実験における気泡放出用のセパレータタ ンクでの気泡除去ならびにセパレータタンクで の空気の吸い込みを考慮して表中の条件とした。

Table 2 Flow conditions in flow experiment

\begin{tabular}{|c|c|}
\hline $\begin{array}{c}\text { Volumetric flux in } \\
\text { liquid phase } \\
j_{l}[\mathrm{~m} / \mathrm{s}]\end{array}$ & $\begin{array}{c}\text { Volumetric flux in } \\
\text { gaseous phase } \\
j_{g}[\mathrm{~m} / \mathrm{s}]\end{array}$ \\
\hline 0 & $0.032-0.206$ \\
\hline 0.042 & $0.045-0.193$ \\
\hline
\end{tabular}

流動実験で得られた結果を Fig.10 および Fig.11 に示吉。Fig.10 は液相流束 $0[\mathrm{~m} / \mathrm{s}] 、 F i g .11$ 以液 相流束 $0.042[\mathrm{~m} / \mathrm{s}]$ における結果であり、図中には 計測時に撮影された代表的な流動様式における 可視化写真がデー夕近傍に示されている。図中に 示されている直線は検定実験により得られた検 定線である。

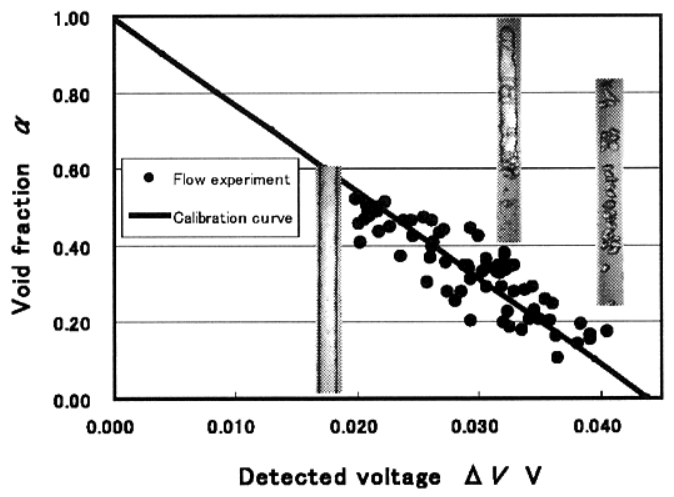

Fig.10 Results of flow experiment $\left(j_{l}=0[\mathrm{~m} / \mathrm{s}]\right)$

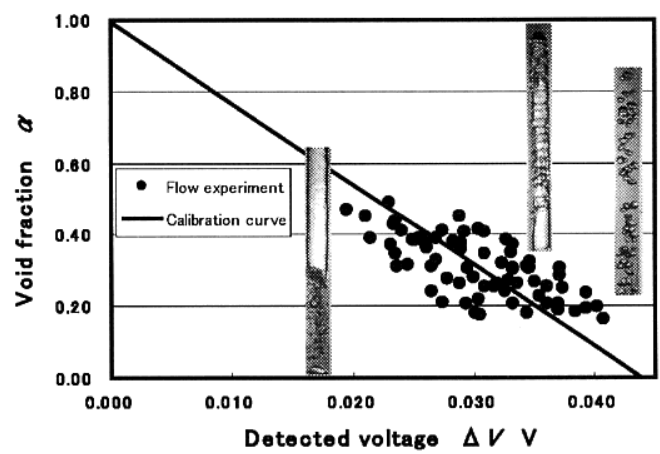

Fig.11 Results of flow experiment $\left(j_{l}=0.042[\mathrm{~m} / \mathrm{s}]\right)$

Fig.10 ならびに Fig.11 において、データにバ ラつきがあるように見受けられるが、締切法その ものが誤差を含む方法であり複数回計測するこ とが推奨されている。そこで、本研究ではまず、 同じ検出起電力において、流動実験で得られたボ イド率と検定線から求められるボイド率の差を 求めた。検定線から求められたボイド率が流動実 験で得られたボイド率より大きい場合屿負の值 をとるものとした。次に、ボイド率の差の平均を 求めることにより、本研究で提案した計測方法の 精度を評価した。その結果、Fig.10において、差 は 1.3 [\%]（ボイド率 0.013）、Fig.11において、差

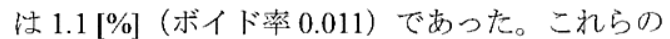
結果より、流動実験の結果恰定線と比較的良い 一致を示していることが分かった。

\section{4 流動実験（ドリフトフラックス㘧゙ルによる検証）}

流動実験において、検出起電力により算出した ボイド率と Zuber-Findlay[9]によるドリフトフラ 
ックスモデルに基づくボイド率の比較を行なっ た。

ドリフトフラックスモデルに基づくボイド率 [10]は、次式で記述される。

$$
\alpha=\frac{\xi /\left\{\xi+(1-\xi) \rho_{g} / \rho_{l}\right\}}{\left.C_{0}+V_{G j} /\left\{\xi / \rho_{g}+(1-\xi) / \rho_{l}\right\} G\right]}
$$

ここで、乡はクオリティ、 $\rho$ は各相の密度、 $C_{0}$ は 分布パラメータ、 $G$ は気相と液相の合計の質量流 量、 $V_{G j}$ は平均ドリフト速度である。分布パラメ 一タ $C_{0}$ と平均ドリフト速度 $V_{G j}$ については気泡流 およびスラグ流において以下の式により求めた。 (気泡流)

$$
\begin{aligned}
& C_{0}=1.2-0.2 \sqrt{\frac{\rho_{g}}{\rho_{l}}} \\
& V_{G j}=\sqrt{2}\left(\sigma g \frac{\rho_{l}-\rho_{g}}{\rho_{l}^{2}}\right)^{\frac{1}{4}}
\end{aligned}
$$

$$
\text { (スラグ流) }
$$

$$
C_{0}=1.2
$$

$$
V_{G j}=0.35\left(\sigma D \frac{\rho_{l}-\rho_{g}}{\rho_{l}}\right)^{\frac{1}{2}}
$$

ここで、 $\sigma$ は表面張力、 $D$ は流路内径である。

液相流束 $0.042[\mathrm{~m} / \mathrm{s}]$ における結果を Fig. 12 に示 寸。気泡流からスラグ流への遷移は数々の見解が あるものの、一般的にボイド率 0.2-0.3とされて いる。そこで、ボイド率 0.2 以下の場合は気泡流 のパラメータを用いてドリフトフラックスモデ ルに基づくボイド率を算出し、0.3 以上ではスラ グ流のパラメータを用いて算出した。なお、ボイ ド率 0.2-0.3 の領域を気泡流からスラグ流への遷 移領域とし、検出起電力により算出したボイド率 とドリフトフラックスモデルに基づくボイド率 との差が小さい場合の流動様式パラメータを採 用した。なお、実験では高ボイド率においてチャ ーン流に属する流動様式が確認されたものの、ス ラグ流とチャーン流の遷移境界の判断は難しい ため、ドリフトフラックスモデルに基づくボイド 率の算出においてはスラグ流として計算した。検 出起電力により算出したボイド率とドリフトフ ラックスモデルに基づくボイド率との差を求め

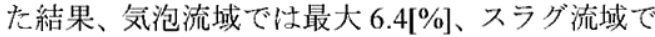
は最大 9.2[\%]であった．また、全領域での差の平 均は $1.1[\%]$ であった。

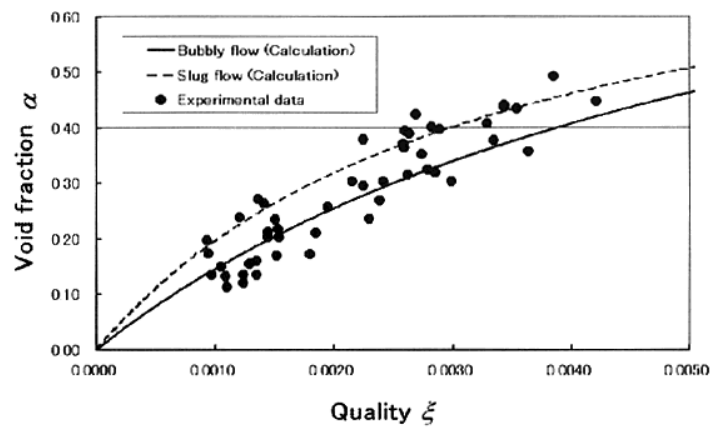

Fig.12 Comparison of void fraction

Fig.13に検出起電力により算出したボイド率 とドリフトフラックスモデルに基づくボイド率 との差 $1[\%]$ 刻みごとに出現するデータの割合を 示したヒストグラムを示す。ヒストグラムより多 くのデータは $5[\%]$ 以内に収まることが分かる。

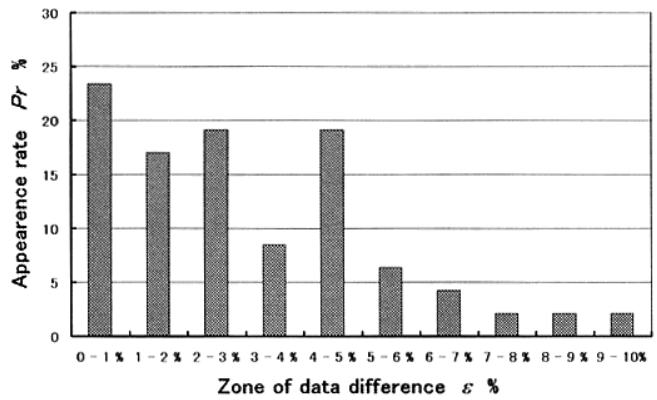

Fig.13 Data appearance rate against to difference rate

本研究では、水-空気系の気液二相流を対象と して水ベース磁性流体を用いたが、液相がオイル 系液体である場合、オイルベース磁性流体を用い ることにより本方法でボイド率の計測が行える。 なお、本研究のボイド率計測方法は、計測対象 の流体と機械的に非接触で行なえるものである。 従来の非接触型ボイド率計測方法として、主に差 圧法、ヨンダクタンス法、X 線法などが挙げられ る。差圧法、コンダクタンス法は比較的低コスト で計測を行なえるものの、流路に加工を施す必要 がある。また、X 線や中性子線を利用する方法で 
はコストが高くなり、装置が大掛かりになり用途 が限定される。これらの方法と比較して、本研究 のボイド率計測方法は、低コストで容易な計測が 行なえる。また、電磁誘導を用いて計測を行なう ため、連続的に計測が行なえ、流路に加丁、を施す 必要が無い。

\section{4. 結 論}

本研究により以下の結論が得られた。

1. $0.1[\mathrm{vol} \%]$ に希釈された磁性流体(W-40)の物 性は蒸留水とほぼ同じであることが計測に より確認された。また、流動可視化実験にお いても異差がないことが確認された。

2. 気液界面にてて発生する磁気分極の影響は理 論上、非常に小さく、気泡形状が気液二相状 態の希釈磁性流体に及ぼす影響は無視でき る。このことを考虑すると、気液二.相状態の 見かけの磁化の理論式より、ボイド率と検出 起電力の関係は線形であることが示された。

3. ボイド率と検出起電力の関係を検証する検 定実験からもボイド率と検出起電力の間に は線形関係が成り立つことが確認された。

4. 本研究で提案されたボイド率計測方法の実 用性を検証する流動において、検定実験より 得られた検定線と流動実験結果の差が比較 的小さいことが確認された。

以上より、対象となる液相に $0.1[\mathrm{vol} \%] \sigma$ 希釈磁 性流体になるように微量の磁性流体を添加し、電 磁誘導在利用することにより、一般的な流体の気 液二相流のボイド率計測が可能であることが分 かった。

\section{謝 辞}

本研究は、文部科学省学術フロンティア推進事 業「次世代ゼロエミッションエネルギー変換シス テム」の支援を受けた。ここに記して謝意を表す る。

\section{Nomenclature}

B : Magnetic flux density

$\Delta$ B : Detected magnetic flux density

$C_{0}$ : Distribution parameter

$D$ : Inner diameter of flow pipe

$G$ : Mass flow rate

H : Magnetic field
$[-]$

[m]

$[\mathrm{kg} / \mathrm{s}]$

$[\mathrm{A} / \mathrm{m}]$
M : Magnetization

$[\mathrm{A} / \mathrm{m}]$

$N$ : Demagnetization factor $\quad[-]$

$P$ : Pressure $[\mathrm{Pa}]$

$S \quad:$ Inner area of induction coil $\quad\left[\mathrm{m}^{2}\right]$

$V$ : Voltage [V]

$\Delta V:$ Detected voltage [V]

$V_{R M S}:$ Root mean square value of voltage [V]

$V_{G j}:$ Mean drift velocity [m/s]

$g:$ Acceleration of gravity $\left[\mathrm{m} / \mathrm{s}^{2}\right]$

$j$ : Volumetric flux of gaseous phase $[\mathrm{m} / \mathrm{s}]$

$n \quad$ : Winding turn of excitation coil [-]

(Greek letters)

$\alpha:$ Void fraction $\quad[-]$

$\rho:$ Density $\quad\left[\mathrm{kg} / \mathrm{m}^{3}\right]$

$\sigma:$ Surface tension $\quad[\mathrm{N} / \mathrm{m}]$

$\xi$ : Quality [-]

(Subscripts)

$g$ : Gas phase

$l \quad:$ Liquid phase

$m f$ : Magnetic fluid

$T \quad$ : Total of liquid phase and gas phase

\section{参考文献}

[1] 日本混相流学会編，混相流ハンドブック，朝 倉書店, 88-97, (2004).

[2] Sekoguchi, K., Takeishi, M., Hironaga, K. and Nishimura T., Measuring Techniques in Gas-Liquid Two-Phase Flows, Springer, Berlin, (1984).

[3] Sekoguchi, K., Takeishi, M., Kano, H., Hironaga, $\mathrm{K}$. and Nishimura, T., Proceedings of $2^{\text {nd }}$ Int. Symposium, Application of Laser Anemometry to Fluid Mechanics, Lisbon, 1-5, (1984).

[4]混相流レクチャーシリーズ 第 25 回 [基礎 と忘用] 混相流の実験・計測技術の基礎，日 本混相流学:会主催, 15-24, (2001).

[5] Rosensweig, R.E., Ferrohydrodynamics, Cambridge University Press, 131-176, (1985).

[6] 石本 淳, 大久保雅章，神山新一，機論 B 61-581, 157-165, (1995).

[7] Ishimoto, J., Kamiyama, S., JMMM 289, 260-263, (2005)

[8] Shuchi, S., Mori, T. and Yamaguchi, H., IEEE Transaction on Magnetics 38, 3234-3236, (2002).

[9] Zuber, N. and Findlay, J.A., Trans. ASMF; J. Heat Transfer, 87, 453-468, (1965).

[10] 日本機械学会編，気液二相流技術ハンドブ シク，コロナ社, 78-83, (1989). 